\title{
CHEF'S COMPETENCY AS A KEY ELEMENT IN FOOD TOURISM SUCCESS: A LITERATURE REVIEW
}

\author{
Tuatul MAHFUD* \\ Yogyakarta State University, Graduate School, Colombo St. No.1, Yogyakarta 55281, Indonesia; \\ Balikpapan State Polytechnic, Hospitality Department, Soekarno Hatta St. Km. 8, \\ Balikpapan 76126, Indonesia; e-mail: tuatul.mahfud@poltekba.ac.id
}

\author{
PARDJONO \\ Yogyakarta State University, Graduate School, Colombo St. No.1, \\ Yogyakarta 55281, Indonesia; e-mail: pardjono@uny.ac.id \\ Badraningsih LASTARIWATI \\ Yogyakarta State University, Department of Food Engineering Education, \\ Colombo St. No.1, Yogyakarta 55281, Indonesia; e-mail: badra@uny.ac.id
}

\begin{abstract}
Citation: Mahfud, T., Pardjono, \& Lastariwati, B. (2019). CHEF'S COMPETENCIES AS A KEY ELEMENT IN FOOD TOURISM SUCCESS: A SHORT LITERATURE REVIEW. GeoJournal of Tourism and Geosites, 26(3), 1057-1071. https://doi.org/10.30892/gtg.26329-417
\end{abstract}

\begin{abstract}
The chef expertise is considered a key to food tourism success. However, studies to identify the competencies of successful chefs are still scarce. This literature review study aims to identify the chef's skill to succeed in his career. There are 38 relevant articles reviewed using the grounded theory method. The results reveal that the chef's competencies include functional competencies, core competencies, and general competencies. The chef's functional competency is culinary expertise that provides for cooking skills, taste and food knowledge, and service tightening. Chef's core competencies include conceptual ability, cleanliness, and business sense. Meanwhile, general competence consists of interpersonal, leadership, managerial, and motivational skills. The identification of chef competencies is used as a guide for culinary educators and trainers for sustainable careers development in the culinary profession.
\end{abstract}

Keywords: chef, competencies, culinary, hospitality, food tourism

\section{INTRODUCTION}

Food tourism has been identified as a nation's vital potential in the future, especially in improving the country's economy (Ian, 2016). Food tourism can increase the interest of tourists to visit a country as a tourist destination, and simultaneously also affect the country's economic improvement (Sharma \& Sharma, 2019). Previous studies have stated that which influences tourist satisfaction is the quality of tourism products,

\footnotetext{
* Corresponding author
} 
including culinary products (Kalebos, 2016). Also, culinary motivations form one of the reasons tourists travel to particular destinations (Expedia, 2016). Approximately 20\%$30 \%$ of total travel expenses are allocated to the food and beverage sector, most refering to restaurants (Paulsson, 2014). This encourages food producers, including hotels, restaurants, caterers, to competitively meet the needs of culinary tourism experiences of tourists (Hall \& Sharples, 2003). The tourist's satisfaction in their culinary travel experience is mostly determined by how well the quality of the culinary products is presented (Kristanti et al., 2018). Meanwhile, the quality of the culinary products also depends heavily on the skills of the chef in processing culinary products.

This culinary quality is considered to significantly affect the experience of customers visiting places to eat (Chen et al., 2016). Thus, the chef's skills for processing and serving culinary products are the primarily key to the success of food tourism. Chefs are culinarians in their professional fields, preparing food and dishes in all ways of operating a restaurant. The chef is known as a professional cook or commonly known as the chief cook in a restaurant or hotel (Oxford Dictionary Online, 2019). The roles of a chef are plentiful, as he is seen as a manager, innovator, taste expert, and artist by many people both inside and outside the culinary field (Culinary Institute of America, 2012). The chef's ability to present a pleasant dining experience for guests is considered very important. Therefore, their creativity in finding new ideas and creating culinary dishes is the primary key to providing a positive experience of guest dining. Chef, as one of the creative people in tourism development, is a valuable resource (Zhang \& Yu, 2018). Pang (2017) suggests that chefs play an essential role in providing content that encourages gastronomic discourse and also in providing a good experience on the plate to visitors.

In many tourism and hospitality literature, the chef role is said to be very vital and needs to get more attention, especially for developing the chef's capacity and ability to support the success of food tourism. Presently, although becoming a chef is easier now than before, becoming a professional chef is considered much more difficult, especially for newcomers (Baldwin, 2018). Learning the criteria for becoming a professional chef is one way to prepare a professional chef. One of the ways of developing professional chefs can be through culinary vocational training that gives chefs the ability to make dishes that inspire visitors' imagination (Pang, 2017). Similarly, culinary education institutions can prepare individuals to acquire culinary skills/knowledge that they will master (Müller, VanLeeuwen, Mandabach, \& Harrington, 2009). Then the question is, what are the criteria for becoming a professional chef? The development of the chef's profession is a critical aspect for food tourism success, it is thereby strongly considered necessary to identify the competency needs of professional chefs. Therefore, the scope of this paper synthesizes the literature on chef competency as a critical element to food tourism success. The literature review of this study includes a discussion of the misperception of the meaning behind chef, the dimensions of competence, and the chef's competence. The results of the chef's competence literature study can be used as a reference for educational and training institutions to prepare prospective workers or for chefs to improve their skills.

\section{METHODS}

This study adopts a literature review approach. The selection of this study approach is intended to reveal the misperception of the chef meaning, the chef's competence definition, and the chef's competence. This literature review method refers to grounded theory (Wolfswinkel et al., 2013) that allows researchers to identify gaps in the field and to build theoretical models based on emerging results. The literature review process refers to the steps proposed by Wolfswinkel et al. (2013). According to their study, there are five steps in conducting the literature review method, which include: 1) determining criteria; 2) 
search; 3) choose; 4) analysis (synthesis), and 5) presentation. Literature review of this study uses criteria for topics on chef competency and the literature sources include articles in journals published from 2000 to 2019. The range of articles in this study by searching databases such as the Emerald page (https://www.emerald.com), Taylor and Francis online (https://www.tandfonline.com), and Science Direct (https://www.sciencedirect.com). Searched keywords used were "chef" OR "chef skill" OR "chef competencies" OR "chef core competencies". Furthermore, the selected articles were chosen based on their suitability for this study, totaling 83 articles consisting of 29 articles from Emerald publications, 22 articles from Taylor and Francis Online publisher, and 32 articles from Sciencedirect.

\section{RESULTS DISCUSSIONS}

From the literature review about chef competence, 38 empirical studies were found whose findings answered this study question. The article review results are grouped into three sub-sections, namely misconceptions about the chef definition, the chef's competence definition, and the chef's competence.

\section{Misconceptions about the chef definition}

The term chef often used synomously to "cook". When referring to the two terms, it is important to note that the use of each term has a different meaning. Although there is no single professional organization that precisely determines the meaning of cooks and chefs, most studies agree that the difference lies in education and experience. Someone who has just started cooking in a home kitchen or just entered the cook's profession at a regular restaurant is called "cook". However, if someone who has a culinary degree through education or training by a professional chef, is usually considered a chef. In other words, it can be concluded that "cook" has a lower rating than "chef".

On the one hand, the term chef in English refers to its French origination, namely chef de cuisine, which means the head of the kitchen. The word "chef" is usually used in professional job positions in the hospitality sector. According to Oxford Dictionary Online (2019), the term chef is a professional cook or commonly known as the chief cook in a restaurant or hotel. Thus, the chef is one who is professionally trained, proficient in all aspects of food preparation and often focuses on certain dishes. According Jones (2011), the chef criteria includes having a two or four year culinary education degree (diploma), taking extensive training under a chef with the aim of getting culinary education equivalent to a bachelor's degree (also known as a culinary apprenticeship), having responsibilities including supervisory roles, has the ability to create and implement menus, and is able to manage the kitchen. Referring to the organizational structure within the kitchen, the profession of chef has different position levels and consequently different job descriptions at each level of office. The levels of chef positions in professional kitchens ranging from the highest to the lowest, include executive chef, sous chef, chef de partie, demi chef, commis (cook), and cook helper. In the structure of the chef position in a professional kitchen, it can be found that the term cook refers to, or is equivalent to, the position of commis. Commis has the duty and responsibility to prepare and process the basic raw materials. On the other hand, cooks or cooks in the general sense are meaningful as people who prepare food to eat (Oxford Dictionary Online, 2019).

Another definition, "cook" is a profession for individuals who prepare food for consumption in the food industry in settings such as in restaurants (Wikipedia, 2019). The cook criteria include being able to prepare food, being able to perform kitchen tasks according to needs and direction, being able to clean the kitchen area, being able to implement recipes or other people's menu plans, and still at the level of learning in his career (Jones, 2011). Thus the two terms between cook and chef in a professional manner cannot be equated. This study uses "chef" term for literature review. 


\section{Definition of chef's competence}

In a general approach, competence can be characterized as a combination of knowledge, skills, and attitudes needed to work well in certain situations in a profession setting (Verhaeghe et al., 2011). According to ASEAN (2013), competency is all about verifiable performance, which includes knowledge, skills, and attitudes related to a system or a set of minimum standards needed for effective performance in the workplace. According to Dumitrescu et al. (2014), competency includes not only a set of knowledge, but also a set of abilities, attitudes, and values. Meanwhile, Tuparova et al. (2014) express competencies as a combination of knowledge, skills, and attitudes that are appropriate to the context. The knowledge aspect identifies what knowledge is needed for a person to work in an informed and effective way. The aspect of skills describe the application of knowledge to situations where understanding is transformed into work results. The attitude aspect explains the reasons for the establishment behind the need for specific knowledge or why skills are done in a certain way. Competence covers all aspects of performance in the workplace and involves, among others: performing individual tasks, managing various tasks, responding to possibilities or damage, dealing with responsibilities at work, working with others (ASEAN, 2013). Chef competency definition was expressed by Birdir and Pearson (2000), where according to him the chef's competence is the skill, ability, knowledge, and other attributes that encourages a successful chef. The chef is successful not because they know how to cook, but because they understand the influence of food on a plate (Pratten, 2003). According to Pratten (2003), mastering cooking techniques does not guarantee one to become a successful chef. That is, being a successful chef requires another set of competencies to support cooking skills. Thus, chef competence is a standard criterion including the knowledge, attitudes, and skills needed for the role and function as a chef.

\section{Chef's Competency}

At the eleventh meeting of the ASEAN Task Force on Tourism Manpower Development, there was a set of minimum competency standards within the framework of qualifications for professionals in travel, housekeeping, front office and food and beverage service companies. These competency standards are based on the competencies needed to carry out a series of positions that are mutually agreed upon in companies within the tourism sector. The competency standards development known as the ASEAN Common Competency Standards for Tourism Professionals (ACCSTP) is based on the concept of competence which consists of knowledge, skills, and attitudes that must be owned and obtained by individuals to work effectively in the workplace (ASEAN, 2013).

Competency standards for tourism professionals listed in the ACCSTP Framework are minimum competency standards (knowledge, skills, and attitudes) that can be accepted and needed by industry and employers as the skill standards of people who meet the requirements to be recognized and valued fairly in ASEAN countries. The minimum competency or minimum terms only refers to the basic skills needed for a particular job description. In the ACCSTP Framework, competency components that include knowledge, skills, and attitudes are represented in three related skill groups, namely functional competencies, core competencies, and generic competencies. Functional competencies are the particular competencies needed to perform roles or jobs in the division of work and include skills and specialized knowledge (know-how) to work effectively, such as the ability to receive and process orders, provide housekeeping services for guests, and operate bar facilities (ASEAN, 2013). Furthermore, according to ASEAN (2013), core competencies are competencies agreed upon by industry, and it is essential to be achieved by a person in order to be accepted as a competent workforce in a particular primary division of labor. These competencies are directly related to the main work tasks and include units such as working effectively with colleagues and customers and implementing occupational health 
and safety procedures (ASEAN, 2013). Whereas general competence is a competency agreed upon by the industry, and it is vital to be achieved if a person must be accepted as a competent workforce in a particular secondary work division. General competence is often associated with the term life skill, the ability to use common tools and technology, and the ability to manage and resolve conflict situations. Referring to the understanding of the three groups of competencies (core competencies, general competencies, and functional competencies), it can be concluded that the chef's skills include all three elements consisting of core competencies, general competencies, and functional competencies (Figure 1).

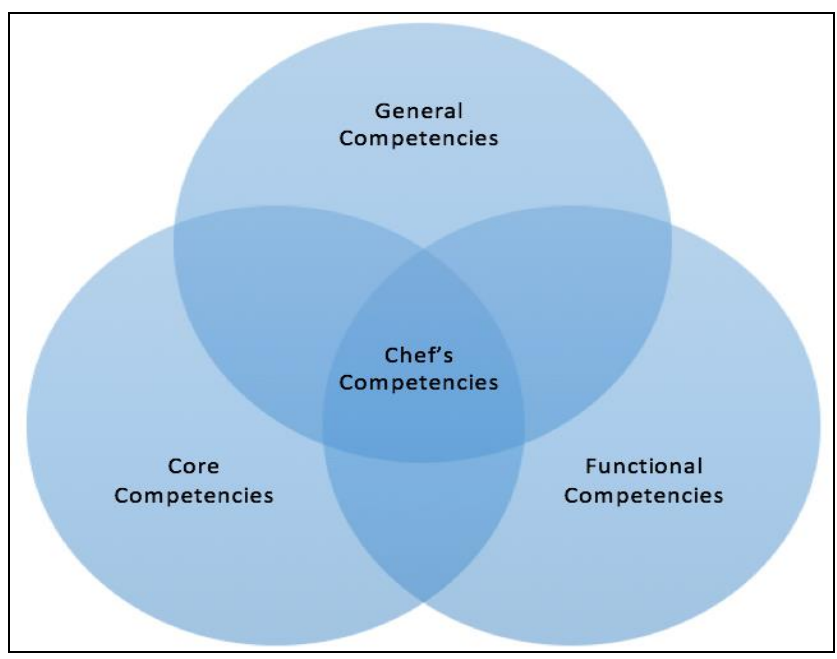

Figure 1. Chef's Competency Dimension

The synthesis to the chef's competency in the literature review study is a reference to the three competency dimensions consisting of functional, core, and general competencies. The results of previous studies on chef competencies are grouped into three dimensions. Furthermore, these three dimensions are broken down into several critical competencies needed for chefs to become successful and professional. The dimension of functional competency points to the chef's culinary skills such as the knowledge of cooking techniques, taste knowledge, culture, and presentation of food. The core competency dimension includes conceptual skills (creativity and aesthetics), business sense, cleanliness, and food security. Finally, the general competence dimensions of chefs include interpersonal, leadership, managerial, and motivational skills. Table 1 presents the results of the literature synthesis reviewing the ability of chefs from previous studies. In their study, Birdir and Pearson (2000) aimed at identifying the competency needs of a chef through the use of the Delphi technique, and revealed that there were ten main priorities of a chef's competence, namely: (1) knowledge of taste; (2) knowledge about food sanitation; (3) the ability to distinguish quality levels in food products; (4) general communication skills (verbal, written, listening); (5) ability to make decisions; (6) the ability to conceptualize new products, processes, systems; (7) the ability to control the ego; (8) the ability to see thoroughly (big picture); (9) the ability to work in a multi-task environment; (10) the ability to prioritize projects.Meanwhile, another study conducted by $\mathrm{Hu}$ (2010) aimed at investigating the core competencies of chefs through in-depth interviews, Delphi and Analytic Network Process (ANP). The study revealed that there are seven essential dimensions of chef's core competencies, namely product mastery, culture, management, service, aesthetics, creativity, and technology. A chef must be able to develop various skills, 
ranging from hard skills related to cooking to soft skills related to working with, and managing, work teams. According to Doyle (2018), there are ten lists of the most essential skills for a chef, namely: attention to detail, business sense, cleanliness, creativity, culinary expertise, fast-paced decision making, motivational, multitasking, organization, team player.

Table 1. Chef Competencies Identification

\begin{tabular}{|c|c|c|c|c|}
\hline No & \begin{tabular}{|l|} 
Dimension \\
\end{tabular} & Competency & Indicator & Source \\
\hline \multirow{5}{*}{1} & \multirow{5}{*}{$\begin{array}{l}\text { Functional } \\
\text { Competence }\end{array}$} & \multirow{5}{*}{$\begin{array}{l}\text { Culinary } \\
\text { expertise }\end{array}$} & Food processing & $\begin{array}{l}\text { Antun \& Salazar (2005); Zopiatis } \\
\text { \& Constanti (2007); Hegarty } \\
\text { (2008); Hegarty \& Antun (2010); } \\
\text { Bosselman (2016); Johnston \& } \\
\text { Phelan (2016); Doyle (2018) }\end{array}$ \\
\hline & & & Foodservice knowledge & Zopiatis (2010); Chen et al. (2016) \\
\hline & & & Knowledge of culinary taste & Zopiatis (2010); Ulloa (2019) \\
\hline & & & Food knowledge and culture & $\begin{array}{l}\text { Birdir \& Pearson (2000); Palmer et } \\
\text { al., (2010); Yang \& Mattila (2019) }\end{array}$ \\
\hline & & & $\begin{array}{l}\text { Knowledge of recipes } \\
\text { and menu development }\end{array}$ & Zopiatis (2010) \\
\hline \multirow{11}{*}{2} & \multirow{11}{*}{$\begin{array}{l}\text { Core } \\
\text { Competence }\end{array}$} & \multirow{4}{*}{ Conceptual } & Innovation & $\begin{array}{c}\text { Ottenbacher \& Harrington (2007); } \\
\text { Robinson \& Barron (2007); } \\
\text { Cousins, O’Gorman, \& Stierand } \\
\text { (2010); Hu (2010); Zopiatis } \\
\text { (2010); Hoholm \& Strønen (2011); } \\
\text { Stierand \& Dörfler (2012); } \\
\text { Hjalager et al., (2015); } \\
\text { Abecassis-Moedas, et al., (2016); } \\
\text { Bharwani et al., (2019) }\end{array}$ \\
\hline & & & Change & Zopiatis (2010) \\
\hline & & & $\begin{array}{l}\text { Artistic culinary } \\
\text { creativity }\end{array}$ & $\begin{array}{l}\text { Horng \& Hu (2008); Chuang et } \\
\text { al., (2009); Hu (2010); Robinson } \\
\text { \& Beesley (2010); Zopiatis (2010); } \\
\text { Stierand \& Dörfle (2012); } \\
\text { Robinson et al., (2014); Hjalager } \\
\text { et al. (2015); Hjalager, Johansen, } \\
\text { \& Rasmussen (2015); Tongchaiprasit } \\
\text { \& Ariyabuddhiphongs (2016); } \\
\text { Warde (2016); Pang (2017); Leung } \\
\text { \& Lin (2018); Zhang \& Yu (2018) }\end{array}$ \\
\hline & & & Product aesthetics & Eburne (2010); Hu (2010); \\
\hline & & \multirow{2}{*}{$\begin{array}{l}\text { Hygiene and } \\
\text { food safety }\end{array}$} & $\begin{array}{l}\text { Food quality } \\
\text { and safety }\end{array}$ & $\begin{array}{l}\text { Birdir \& Pearson (2000); Zopiatis } \\
\text { (2010); Bosselman (2016); Rebouças } \\
\text { et al., (2017); Stluka et al., (2018) }\end{array}$ \\
\hline & & & Cleanliness and healthy & $\begin{array}{c}\text { Middleton (2000); Hertzman \& } \\
\text { Stefanelli (2008); Hertzman \& } \\
\text { Ackerman (2010); Polak et al., } \\
\text { (2015); Doyle (2018) }\end{array}$ \\
\hline & & \multirow{5}{*}{$\begin{array}{l}\text { Business } \\
\text { sense }\end{array}$} & Cost management & Zopiatis (2010) \\
\hline & & & Implement labor cost control & Zopiatis (2010) \\
\hline & & & Budgeting & Zopiatis (2010) \\
\hline & & & Strategic planning & $\begin{array}{l}\text { Harrington (2005); Zopiatis } \\
\text { (2010); Nelson et al., (2017); Jha } \\
\text { \& Bhattacharyya (2018) }\end{array}$ \\
\hline & & & Business skills & $\begin{array}{c}\text { Birdir \& Pearson (2000); } \\
\text { Ladkin (2000); Surlemont et al., }\end{array}$ \\
\hline
\end{tabular}


Chef's Competency as a Key Element in Food Tourism Success: A Literature Review

\begin{tabular}{|c|c|c|c|c|}
\hline No & Dimension & Competency & Indicator & $\begin{array}{c}\text { Source } \\
\end{array}$ \\
\hline & & & & $\begin{array}{l}\text { (2005); Harringon \& Herzog } \\
\text { (2007); Bosselman (2016); Allen \& } \\
\text { Mac Con Iomaire (2017); Doyle } \\
\text { (2018); Laneyrie et al., (2018); } \\
\text { Presenza \& Petruzzelli (2019) }\end{array}$ \\
\hline \multirow{17}{*}{3} & \multirow{17}{*}{$\begin{array}{c}\text { General } \\
\text { Competency }\end{array}$} & \multirow{3}{*}{ Interpersonal } & Communication skills & $\begin{array}{c}\text { Birdir \& Pearson (2000); } \\
\text { Harrington (2005); Robinson et } \\
\text { al., (2010); Zopiatis (2010) }\end{array}$ \\
\hline & & & Teamwork & $\begin{array}{l}\text { Balazs (2002); Mac Con Iomaire } \\
\text { (2008); Wang (2013); Savino et } \\
\text { al., (2017); Doyle (2018) }\end{array}$ \\
\hline & & & Knowledge of diverse cultures & Zopiatis (2010) \\
\hline & & \multirow{5}{*}{ Leadership } & Decision making skills & $\begin{array}{l}\text { Birdir and Pearson (2000); } \\
\text { Harrington (2005); Zopiatis } \\
\text { (2010); Doyle (2018) }\end{array}$ \\
\hline & & & Ethical contact & Zopiatis (2010) \\
\hline & & & $\begin{array}{l}\text { Emotional control } \\
\text { and stability }\end{array}$ & $\begin{array}{l}\text { Murray-Gibbons \& Gibbons } \\
\text { (2007); Zopiatis (2010) }\end{array}$ \\
\hline & & & Emotional intelligence & $\begin{array}{c}\text { Zopiatis (2010); H.-T. Chen \& } \\
\text { Wang (2019) }\end{array}$ \\
\hline & & & Leadership skills & $\begin{array}{c}\text { Allen \& Mac Con Iomaire } \\
\text { (2017); Haddaji et al. (2017); } \\
\text { Swift et al., (2019) }\end{array}$ \\
\hline & & \multirow{6}{*}{ Managerial } & Delegate and organize & $\begin{array}{c}\text { Birdir \& Pearson (2000); } \\
\text { Zopiatis (2010); Allen \& Mac } \\
\text { Con Iomaire (2017): Dovle (2018) }\end{array}$ \\
\hline & & & Time management & Robinson et al., (2010); Zopiatis \\
\hline & & & Organizational skills & Zopiatis (2010); Doyle (2018) \\
\hline & & & Handle staff complaints & Zopiatis (2010) \\
\hline & & & Assessing staff & Zopiatis (2010) \\
\hline & & & Managerial skills & $\begin{array}{c}\text { Allen \& Mac Con Iomaire } \\
\text { (2017); Laneyrie et al., (2018); } \\
\text { Swift et al., (2019) }\end{array}$ \\
\hline & & \multirow{3}{*}{ Motivational } & Ability to motivate others & $\begin{array}{l}\text { Balazs (2002); Zopiatis \&Constanti } \\
\text { (2007); Zopiatis (2010); Allen \& Mac } \\
\text { Con Iomaire (2017); Doyle (2018) }\end{array}$ \\
\hline & & & Self motivating ability & Zopiatis \& Constanti (2007) \\
\hline & & & $\begin{array}{c}\text { Willpower, obsession, and } \\
\text { tenacity }\end{array}$ & Mac Con Iomaire (2008) \\
\hline
\end{tabular}

\section{Culinary expertise}

Many experts agree that the competencies that need to be mastered by a chef in order to be successful in his career, those related to culinary expertise and professional competence (Ko, 2012). Culinary expertise is the technical expertise that includes knowledge and skills related to the profession of the chef. Simililarly, in the study by Birdir and Pearson (2000), the results of this study identifyed the competency needs of a chef, with the Delphi technique comprising of 33 members of The Research Chef Association revealed that a chef must know the taste and have the ability to distinguish quality levels in food products. The results of this studies also prove that culinary technical expertise has priority interest in development. Other scholars also revealed that chefs must master food processing (Antun \& Salazar, 2005; Bosselman, 2016; 
Johnston \& Phelan, 2016; Zopiatis \& Constanti, 2007). For instance, a study conducted by Shyr, Pan, Huang, and Chang (2018) states that a teppanyaki chef must have four competency dimensions consisting of knowledge, technique, affect and attitude.

Zopiatis (2010) stated that this culinary expertise includes knowledge of foodservice operations, knowledge of culinary flavors, and knowledge of recipe and menu development. Knowledge and technical skills in the form of mastery of cooking techniques for important chefs are known as the primary capital of developing culinary products. The chef must follow the development of culinary information based on cultural characteristics and cooking technology. Hu (2010) stated that the chef must also own the mastery of products and culture. Chefs who are unable to keep up with the development of cultural trends and cooking technology will be very quickly left behind and unable to compete. The study conducted by Baldwin (2017) about the transference of Asian hospitality through food explains how Asian cuisine and culture inspires new dishes and menu items for chefs around the world.

According to him, today's chefs use various tools to gather inspiration and gain new knowledge, including culture. But what needs to be highlighted is that a successful chef does not mean a chef who can cook something, but a chef who understands and can create foods that taste high and ultimately favor consumers.

\section{Conceptual (innovation, creativity, and aesthetics)}

Food tourism sustainability depends on the creativity of the chef to create exciting culinary products. Maybe many chefs can cook food, but few of them can create innovative and creative food products. This skill is the key to ensuring food tourism sustainability. Food tourism that can innovate food and beverage products every time will be able to las long term in business competition. Another study conducted by $\mathrm{Hu}$ (2010), which aims to investigate the core competencies of chefs through in-depth interviews, Delphi, and Analytic Network Process (ANP), revealed that there are seven essential dimensions of chef's core competencies and one of them is creativity and aesthetics. Similarly, scholar (Horng \& Hu, 2008; Hu, 2010; Jeou-Shyan \& Lee, 2009; Zopiatis, 2010) states that chefs must master artistic culinary creativity.

The future culinary competition is very tight, and chefs need to learn more about how to control the creative process and innovation (Albors-Garrigos et al., 2013; Leung \& Lin, 2018; McBride \& Flore, 2019). Besides, the courage and ability to innovate for chefs is also significant (Abecassis-Moedas et al. 2016; Hu, 2010; Robinson \& Barron, 2007; Zopiatis, 2010). In fact, in their study, Presenza and Petruzzelli (2019) highlighted that innovation became the main driver in the restaurant business relationship. Innovations in cuisine involve the development of new ideas and the incorporation of various aspects of cooking styles such as integrating modern cooking methods in the processing of traditional dishes. Moreover, culinary tourism sustainability is also influenced by efforts to continuously develop culinary products. Periodically, culinary products need to be evaluated and developed, specifically referring to recipes and menus. One of the skills of the chef is being able to conduct culinary product development research (Wan et al., 2017). Tourists reaching boredom in culinary products may be because it does not provide a positive experience of culinary tourism, which can be anticipated by developing recipes and culinary menus by the chef. Of course, the development of recipes and menus is based on SWOT analysis (Strengths, Weaknesses, Opportunities, and Threats) of the market needs to be able to create sustainable culinary products. Processing and serving food is a complex task that requires cooking skills, creativity, innovation, and aesthetics. Because of this, a scientific and conceptual approach can help chefs to work more systematically and 
innovatively. The final touch of culinary products, being to beautify dishes, also needs to be mastered by the chef, such as the ability to decorate dishes and how to serve exciting dishes. This capability will provide a positive experience of culinary tourism for tourists and will ultimately offer tourist satisfaction.

\section{Food hygiene and safety}

Food quality is not only related to extraordinary taste but also concerns whether the food is safe and healthy for consumers. These two aspects are interrelated, creating excellent and healthy food. This situation is also a challenge for chefs on how to cook delicious culinary dishes that are similarly healthy for consumption. The importance of chefs paying attention to aspects of cleanliness and health during the production process is underlined by several scholars (see Birdir \& Pearson, 2000; Bosselman, 2016; Zopiatis, 2010). In discussing cleanliness, attention should be paid the personal hygiene or personal hygiene of the chef, kitchen sanitation, sanitation of kitchen equipment, water sanitation, and others. A chef needs to be aware of the concerns for consumers, starting from how to make consumers satisfied, how they need, and even their healthrelated to the food they consume. This fact is significant in a restaurant, where unhealthy conditions can affect the quality of food, and can even force a restaurant to close. The study conducted by Allen and Mac Con Iomaire (2017) revealed that there are three top criteria for chef success in Ireland, namely hard work, commitment to quality, and Hazard Analysis and Critical Control Points (HACCP).

Empirically, developing a food safety management system for the food business in the hospitality industry can improve the quality of services, primarily to ensure food security for consumers (Taylor \& Taylor, 2008). HACCP is an internationally recognized food safety management system, and its use is recommended in the hospitality industry. HACCP is a way to ensure that the food consumed by customers is safe and healthy. Another study states that good food security knowledge and practice is one of the qualifications of a chef (Rebouças et al., 2017). Thus, the principles of hygiene are part of the competencies considered necessary for the chef's profession and maintaining quality while working in the kitchen area, as this responsibility lies with the chefs.

\section{Business sense}

A top chef is also an excellent entrepreneur. He must always think about how to make delicious food while saving costs that can increase profits. Previous studies also proved that business skills are one of the essential skills of a chef (Allen \& Mac Con Iomaire, 2017; Birdir \& Pearson, 2000; Bosselman, 2016; Ladkin, 2000). Professional chefs are not only encouraged to master how to cook but they must be able to develop business activities for culinary products that they make, such as determining the food cost of culinary products, selling prices of products, to how the product is popular and profitable. Zopiatis (2010), investigated chefs' perceptions of chef competency requirements needed for successful careers in the industry, the study concluded that chefs must have cost management capabilities, cost control, and budgeting.

Top chefs are generally involved in entrepreneurial activities so as to always innovate without limits and maximize their reputation for higher profits (Presenza \& Petruzzelli, 2019). The study conducted by Balazs (2002) holds that the key to the success of top chefs in France is directly related to the involvement in entrepreneurial or business activities. Also, a chef must be able to endorse culinary products that he cooks to be known by consumers (Luoh \& Lo, 2012). The chef's business skills are needed to increase restaurant income (Surlemont et al., 2005). The importance of business skills of a chef encourages HRD to facilitate business management training activities for chefs (Laneyrie et al., 2018). 


\section{Interpersonal}

Literature on food and beverage services, especially culinary tourism, highlight the importance of providing customers satisfaction. In this context, developing a chef's image is very important to create excellent service quality. The chefs performance is not only related to cooking skills, but includes excellent interpersonal skills. Building functional interactions with customers and coworkers is one way to create an excellent culinary experience. According to Chen et al. (2016) communication with customers positively influences their culinary experience. Other scholars (Mahfud et al., 2017) state that communication skills are a top priority for working in food and beverage production (kitchen). Zopiatis (2010) describes interpersonal skills as those including communication skills, verbal and writing skills, and knowledge of diverse cultures. Another scholars maintain that one of the interpersonal chefs need to be develop are communication skills (Birdir \& Pearson, 2000; Harrington, 2005).

Effective communication skills for chefs are required to be able to facilitate effective medium in conveying information and ideas. The meaning of communication in this context includes both verbal and non-verbal communication. The chef should not only has adequate verbal communication skills but additionally non-verbal communication. A study conducted by Sohn and Lee (2018), on the influence of nonverbal communication by chefs in open kitchens on service quality, revealed that chefs non-verbal communication, including paralanguage, kinesic, proxemic, and physical appearance, was related to service quality.Also, building relationships in complicated work situations in the kitchen is essential. A good team relationship starts from the shared understanding between team members and subsequently forms the commitment of chef members to teamwork (Suhairom et al., 2019). Numerous other studies also revealed that chefs must be able to work together in teams (Balazs, 2002; Doyle, 2018; Mac Con Iomaire, 2008). The organizational structure and tasks in complex kitchens are in dire need of teamwork by the chefs so that work operations can run effectively. Good teamwork can help create timeliness in the presentation of guest food orders. Food processing requires speed and timeliness so that it can be served fresh in front of guests.

\section{Leadership}

Leadership practices carried out by chefs in restaurant kitchens are also demonstrated by Wellton et al. (2017). This study revealed that the leadership aspect is needed a head chef to improve their product quality and reputation as a professional chef. This research opined that horizontal leadership practices in the restaurant industry leads to the possibility of a new order for growth and development. In addition, the factors needed to succeed in the culinary industry include professionalism, individual characteristics, leadership skills, management skills, and interactions with work contexts (Allen \& Mac Con Iomaire, 2017). Furthermore, according to this study, efforts to strengthen the hotel industry in the future include talent management, guiding future leaders, reducing staff turnover, and curriculum development. Also, chefs play an important role in workplace learning leadership (Cormier-MacBurnie, Doyle, Mombourquette, \& Young, 2015). That is, the development of leadership aspects for a chef is vital, and therefore needs to be mastered by the chef.

\section{Managerial}

Empirically, the need for crucial competencies to become a successful professional chef has been widely studied by experts. For example, a study conducted by Allen and Mac Con Iomaire (2017) found that the success of chefs in Ireland is influenced by factors such as professionalism, individual characteristics, leadership skills, management skills, and interactions with the work context. Chefs are recognized as culinary professionals who are responsible for maintaining high-quality food services 
in hospitality operations. They are therefore required to have planning and management skills (Suhairom et al., 2019), especially in the position of the head chef or executive chef. Managerial skills are needed by executive chefs to manage operations in the food and beverage division. The study conducted by (Wan et al., 2017), on ten executive chefs and executive sous chefs, shows the importance of mastering management skills for the chef's profession. Similarly, Harrington (2005) considers the chef to be the CEO who plans strategic business so that the culinary industry is successful.

\section{Motivational}

The work atmosphere in the kitchen experienced by chefs is full of busyness, pressure, and a large workload. General characteristics of culinary workplaces include long working hours (Mac Con Iomaire, 2008), high-stress levels (Mac Con Iomaire, 2008; Wang et al., 2011), low compensation and limited opportunities for progress in the industry (Jauhari, 2006). Therefore, a chef is required to have a good personality, such as being able to motivate himself and others. A high workload can lead to stress, and as such, the chef must be able to motivate himself always to work productively (Zopiatis \& Constanti, 2007). In theory, motivation is a factor that drives a chef towards better work performance. Other meanings of motivation refer to aspects that encourage, direct, and choose behavior towards specific actions or goals. Also, working within a team in the kitchen requires the chef to be able to motivate the team members to work (Allen \& Mac Con Iomaire, 2017; Balazs, 2002; Zopiatis, 2010; Zopiatis \& Constanti, 2007). Problems experienced by the kitchen staff can also include discipline, cramped conditions, being without fresh air and the weather being too hot, especially in summer (Pratten, 2003). The ability to influence other people by motivating other kitchen staff is crucial to create a productive performance for chefs and other kitchen team members.

\section{CONCLUSION}

Competence is an essential factor that has a tremendous impact on the sustainability of an individual's career, especially in the culinary field. The results of this study show the criteria for successful chefs to support the development of food tourism. Chef's competency is divided into three types, namely functional competencies, core competencies, and general competencies. The chef's functional competency is culinary expertise that includes cooking skills, taste and food knowledge, and service tightening. Core competencies include conceptual ability, cleanliness, and business sense. Meanwhile, general competence consists of interpersonal, leadership, managerial, and motivational skills. This chef's competence is as a guide for culinary educators and trainers for sustainable career development in the culinary profession.

\section{Acknowledgments}

This paper is part of a dissertation project, so we would like to thank the Yogyakarta State University Postgraduate Program for approving the selection of this dissertation topic. Also, I would like to thank the Ministry of Research, Technology and Higher Education of the Republic of Indonesia for supporting the funding of this research.

\section{REFERENCES}

Abecassis-Moedas, C., Sguera, F., \& Ettlie, J. E. (2016). Observe, innovate, succeed: A learning perspective on innovation and the performance of entrepreneurial chefs. Journal of Business Research, 69(8), 28402848. https://doi.org/https://doi. org/10.1016/j.jbusres.2015.12.053.

Albors-Garrigos, J., Barreto, V., García-Segovia, P., Martínez-Monzó, J., \& Hervás-Oliver, J. L. (2013). Creativity and Innovation Patterns of Haute Cuisine Chefs. Journal of Culinary Science \& Technology, 11(1), 1935. https://doi.org/10.1080/15428052.2012.728978. 
Allen, H., \& Mac Con Iomaire, M. (2017). Secrets of a head chef: Exploring factors influencing success in Irish kitchens. Journal of Culinary Science and Technology, 15(3), 187-222. https://doi.org/10.1080/ 15428052.2016 .1225538$.

Antun, J. M., \& Salazar, J. (2005). The impact of learning transfer outcomes on employed culinary arts graduates' perceptions of career success. Journal of Culinary Science \& Technology, 4(1), 75-87. https://doi.org/doi:10.1300/J385v04no1_09.

Balazs, K. (2002). Take one entrepreneur: The recipe for success of France's great chefs. European Management Journal, 2O(3), 247-259. https://doi.org/doi:10.1016/So263-2373(02)00040-3.

Baldwin, W. (2017). The transference of Asian hospitality through food: Chef's inspirations taken from Asian cuisines to capture the essence of Asian culture and hospitality. International Journal of Gastronomy and Food Science, 8(C), 7-13. https://doi.org/10.1016/j.ijgfs.2017.01.002.

Baldwin, W. (2018). Chef's sabbatical: An analysis of chef's gastronomic research through culinary tourism. International Journal of Gastronomy and Food Science, 13, 65-72. https://doi.org/https://doi. org/10.1016/j.ijgfs.2018.05.006.

Bharwani, S., Mathews, D., \& Ghura, A. S. (2019). Business model innovation in the Indian hospitality industry. Worldwide Hospitality and Tourism Themes, 11(4), 362-377. https://doi.org/10.1108/WHATT-04-2019-0018.

Birdir, K., \& Pearson, T. E. (2000). Research chefs' competencies: A Delphi approach. International Journal o Contemporary Hospitality Management, 12(3), 205-209. https://doi.org/10.1108/o9596110010309989.

Bosselman, R. (2016). An Evaluation of the Research Chefs Association's Bachelor of Science in Culinologyß Core Competencies AU - Cheng, Michael. Journal of Hospitality \& Tourism Education, 28(3), 127-141. https://doi.org/10.1080/10963758.2016.1189831.

Chen, A., Peng, N., \& Hung, K. (2016). Chef image's influence on tourists' dining experiences. Annals of Tourism Research, 56, 154-158. https://doi.org/https://doi.org/10.1016/j.annals.2015.11.005.

Chuang, N., Yin, D., \& Dellmann-Jenkins, M. (2009). Intrinsic and extrinsic factors impacting casino hotel chefs' job satisfaction. International Journal of Contemporary Hospitality Management, 21(3), 323340. https://doi.org/10.1108/09596110910948323.

Cormier-MacBurnie, P., Doyle, W., Mombourquette, P., \& Young, J. D. (2015). Canadian chefs' workplace learning. European Journal of Training and Development, 39(6), 522-537. https://doi.org/10.1108/ EJTD-01-2015-0003.

Cousins, J., O’Gorman, K., \& Stierand, M. (2010). Molecular gastronomy: cuisine innovation or modern day alchemy? International Journal of Contemporary Hospitality Management, 22(3), 399-415. https://doi.org/10.1108/o9596111011035972.

Doyle, A. (2018). Chef skills list and examples. Retrieved August 24, 2018, from https://www.thebalancecareers. com/chef-skills-list-2062369.

Dumitrescu, C., Drăghicescu, L., Olteanu, R. L., \& Suduc, A.-M. (2014). Key Competences for Sustainable Development - Aspects Related with SUSTAIN Project Activity. Procedia - Social and Behavioral Sciences, 141, 1101-1105. https://doi.org/https://doi.org/10.1016/j.sbspro.2014.05.185.

Eburne, J. P. (2010). The Chef Drive: Cooking Beyond the Pleasure Principle. Contemporary French and Francophone Studies, 14(2), 169-177. https://doi.org/10.1080/17409291003644909.

Haddaji, M., Albors-Garrigós, J., \& García-Segovia, P. (2017). Women chefs' experience: Kitchen barriers and success factors. International Journal of Gastronomy and Food Science, 9, 49-54. https://doi.org /https://doi.org/10.1016/j.ijgfs.2017.06.004.

Hall, C. M., \& Sharples, L. (2003). The consumption of experiences or the experience of consumption? An introduction to the tourism of taste. In C. M. Hall, L. Sharples, R. Mitchell, N. Macionis, \& B. Cambourne (Eds.), Food tourism around the world: Development, management and markets (pp. 124). Oxford: Butterworth-Heinemann.

Harringon, R., \& Herzog, C. (2007). Chef John Folse: A Case Study of Vision, Leadership \& Sustainability. Journal of Hospitality \& Tourism Education, 19(3), 5-10. https://doi.org/10.1080/10963758.2007. 10696892.

Harrington, R. J. (2005). Chef as CEO: An analogy and teaching tool. Journal of Culinary Science and Technology, 4(1), 39-52. https://doi.org/doi:10.1300/J385v04no1_o6.

Hegarty, J. (2008). What is the Role of the Chef in Contemporary Society? Journal of Culinary Science \& Technology, 6(1), 1-4. https://doi.org/10.1080/15428050701884113.

Hegarty, J., \& Antun, J. (2010). Is the Chemical Chef Dividing Culinary Arts and Gastronomy? Journal of Culinary Science \& Technology, 8(2-3), 73-76. https://doi.org/10.1080/15428052.2010.511095.

Hertzman, J., \& Ackerman, R. (2010). Evaluating quality in associate degree culinary arts programs. Quality Assurance in Education, 18(3), 209-226. https://doi.org/10.1108/09684881011058650.

Hertzman, J., \& Stefanelli, J. M. (2008). Developing Quality Indicators for Associate Degree Culinary Arts Programs: A Survey of Educators and Industry Chefs. Journal of Quality Assurance in Hospitality \& Tourism, 9(2), 135-158. https://doi.org/10.1080/15280o80802235466.

Hjalager, A.-M., Johansen, P. H., \& Rasmussen, B. (2015). Informing regional food innovation through lead user experiments. British Food Journal, 117(11), 2706-2723. https://doi.org/10.1108/BFJ-03-2015-0098. 
Hoholm, T., \& Strønen, F. H. (2011). Innovation, strategy and identity: a case study from the food industry. European Journal of Innovation Management, 14(3), 345-363. https://doi.org/10.1108/1460106 1111148834 .

Horng, J. S., \& Hu, M. L. (2008). The mystery in the kitchen: the developmental process of culinary creativity. Creativity Research Journal, 20(2), 221-230.

Hsi-Tien, C., \& Wang, C.-H. (2019). Incivility, satisfaction and turnover intention of tourist hotel chefs. International Journal of Contemporary Hospitality Management, 31(5), 2034-2053. https://doi.org/ 10.1108/IJCHM-02-2018-0164.

Hu, M.-L. M. (2010). Developing a core competency model of innovative culinary development. International Journal of Hospitality Management, 29(4), 582-590. https://doi.org/https://doi.org/10.1016/ j.ijhm.2009.10.024.

Ian, Y. (2016). The future of food tourism. Journal of Tourism Futures, 2(1), 95-98. https://doi.org/ 10.1108/JTF-12-2015-0051.

Jauhari, V. (2006). Competencies for A Career in The Hospitality Industry: An Indian Perspective. International Journal of Contemporary Hospitality Management, 18(2), 123-134. https://doi.org/10.1108/ 09596110610646673.

Jeou-Shyan, H., \& Lee, Y. (2009). What environmental factors influence creative culinary studies? International Journal of Contemporary Hospitality Management, 21(1), 100-117. https://doi.org/10.1108/ 09596110910930214.

Jha, S., \& Bhattacharyya, S. S. (2018). Online restaurant entrepreneurship: the story of Holachef in an increasingly digitalized India. Emerald Emerging Markets Case Studies, 8(1), 1-17. https://doi.org/ 10.1108/EEMCS-03-2017-0040.

Johnston, N. E., \& Phelan, K. V. (2016). Assessing objective and subjective factors of culinary career success: Exploring the influence of industry certifications. Journal of Culinary Science \& Technology, 14(1), 3658. https://doi.org/doi:10.1080/15428052.2015.1080641.

Jones, G. S. (2011). The Difference Between a Cook and a Chef. Retrieved May 15, 2019, from https://www.reluctantgourmet.com/difference-cook-chef/.

Kalebos, F. (2016). Faktor-faktor yang mempengaruhi kepuasan wisatawan yang berkunjung ke daerah wisata kepulauan. Jurnal Riset Bisnis Dan Manajemen, 4(3), 489-502.

Ko, W.-H. (2012). The relationships among professional competence, job satisfaction and career development confidence for chefs in Taiwan. International Journal of Hospitality Management, 31(3), 1004-1011. https://doi.org/https://doi.org/10.1016/j.ijhm.2011.12.004.

Kristanti, M., Jokom, R., Wijaya, S., \& Widjaja, D. C. (2018). Culinary experience towards behavioral of domestic tourists in Solo and Bandung, Indonesia. Kinerja, 22(2), 186-200.

Ladkin, A. (2000). Vocational education and food and beverage experience: issues for career development. International Journal of Contemporary Hospitality Management, 12(4), 226-233. https://doi.org/ $10.1108 / 09596110010330723$.

Laneyrie, E., Landry, A., \& Rouat, S. (2018). Représentations des chefs cuisiniers quant à leur activité de management: entre performance et prévention des risques. Psychologie Du Travail et Des Organisations. https://doi.org/https://doi.org/10.1016/j.pto.2018.11.001.

Leung, V. T. Y., \& Lin, P. M. C. (2018). Exogenous factors of the creative process and performance in the culinary profession. International Journal of Hospitality Management, 69, 56-64. https://doi.org/ https://doi.org/10.1016/j.ijhm.2017.10.007.

Luoh, H.-F., \& Lo, P.-C. (2012). The Effectiveness of Chef Endorsement in Restaurant Print Advertising: Do Respondents' Gender Stereotypes or Genders Matter? Asia Pacific Journal of Tourism Research, 17(4), 416-431. https://doi.org/10.1080/10941665.2011.627354.

Mac Con Iomaire, M. (2008). Understanding the Heat-Mentoring: A Model for Nurturing Culinary Talent AU Mac Con Iomaire, Máirtín. Journal of Culinary Science \& Technology, 6(1), 43-62. https://doi.org/ $10.1080 / 15428050701884196$.

Mahfud, T., Kusuma, B. J., \& Mulyani, Y. (2017). Soft skill competency map for the apprenticeship programme in the Indonesian balikpapan hospitality industry. Journal of Technical Education and Training, 9(2).

McBride, A. E., \& Flore, R. (2019). The changing role of the chef: A dialogue. International Journal of Gastronomy and Food Science, 17, 100157. https://doi.org/https://doi.org/10.1016/j.ijgfs.2019.100157.

Middleton, G. (2000). A preliminary study of chefs' attitudes and knowledge of healthy eating in Edinburgh's restaurants. International Journal of Hospitality Management, 19(4), 399-412. https://doi.org /https://doi.org/10.1016/So278-4319(oo)ooo18-9.

Müller, K. F., VanLeeuwen, D., Mandabach, K., \& Harrington, R. J. (2009). The effectiveness of culinary curricula: a case study. International Journal of Contemporary Hospitality Management, 21(2), 167178. https://doi.org/10.1108/0959611091093566o.

Murray-Gibbons, R., \& Gibbons, C. (2007). Occupational stress in the chef profession. International Journal of Contemporary Hospitality Management, 19(1), 32-42. https://doi.org/10.1108/09596110710724143.

Nelson, P., Beckie, M. A., \& Krogman, N. T. (2017). The "Locavore" Chef in Alberta: A Situated Social Practice Analysis. Food, Culture \& Society, 2O(3), 503-524. https://doi.org/10.1080/15528014.2017.1288798. 
Ottenbacher, M., \& Harrington, R. J. (2007). The innovation development process of Michelin-starred chefs. International Journal of Contemporary Hospitality Management, 19(6), 444-46o. https://doi.org/ 10.1108/09596110710775110.

Palmer, C., Cooper, J., \& Burns, P. (2010). Culture, identity, and belonging in the "culinary underbelly." International Journal of Culture, Tourism and Hospitality Research, 4(4), 311-326. https://doi.org/10.1108/17506181011081497.

Pang, L. (2017). The training and creativity of professional chefs: Stoking the imagination in global gastronomic discourse. Appetite, 119, 48-53. https://doi.org/https://doi.org/10.1016/j.appet.2017.08.014.

Paulsson, L. (2014). Ekonomiska och sysselsättningsmässiga effekter av turismen i Skåne 2013. Stockholm: Resurs TEM.

Polak, R., Sforzo, G. A., Dill, D., Phillips, E. M., \& Moore, M. (2015). Credentialed Chefs as Certified Wellness Coaches: Call for Action. Eating Behaviors, 19, 65-67. https://doi.org/https://doi.org/10.1016/ j.eatbeh.2015.06.016.

Pratten, J. D. (2003). What makes a great chef? British Food Journal, 105(7), 454-459. https://doi.org/ 10.1108/00070700310497255.

Presenza, A., \& Petruzzelli, A. M. (2019). Investigating business model innovation in Haute Cuisine. Role and behavior of chef-entrepreneurs. International Journal of Hospitality Management, 82, 101-111. https://doi.org/https://doi.org/10.1016/j.ijhm.2019.03.027.

Rebouças, L. T., Santiago, L. B., Martins, L. S., Rios Menezes, A. C., Araújo, M. da P. N., \& Almeida, R. C. de C. (2017). Food safety knowledge and practices of food handlers, head chefs and managers in hotels' restaurants of Salvador, Brazil. Food Control, 73, 372-381. https://doi.org/https://doi.org/ 10.1016/j.foodcont.2016.08.026.

Robinson, R. N. S., Arcodia, C. V., Tian, C., \& Charlton, P. (2010). Cookery-related employment vacancy advertisements and skills shortages. International Journal of Contemporary Hospitality Management, 22(4), 483-499. https://doi.org/10.1108/09596111011042703.

Robinson, R. N. S., \& Barron, P. E. (2007). Developing a framework for understanding the impact of deskilling and standardisation on the turnover and attrition of chefs. International Journal of Hospitality Management, 26(4), 913-926. https://doi.org/https://doi.org/10.1016/j.ijhm.2006.10.002.

Robinson, R. N. S., \& Beesley, L. G. (2010). Linkages between creativity and intention to quit: An occupational study of chefs. Tourism Management, 31(6), 765-776. https://doi.org/https://doi.org/10.1016/ j.tourman.2009.08.003.

Robinson, R. N. S., Solnet, D. J., \& Breakey, N. (2014). A phenomenological approach to hospitality management research: Chefs' occupational commitment. International Journal of Hospitality Management, 43, 65-75. https://doi.org/https://doi.org/10.1016/j.ijhm.2014.08.004.

Savino, T., Petruzzelli, A. M., \& Albino, V. (2017). Teams and lead creators in cultural and creative industries: evidence from the Italian haute cuisine. Journal of Knowledge Management, 21(3), 607-622. https://doi.org/10.1108/JKM-09-2016-0381.

Sharma, S., \& Sharma, R. (2019). Culinary skills: the spine of the Indian hospitality industry. Worldwide Hospitality and Tourism Themes, 11(1), 25-36. https://doi.org/10.1108/WHATT-10-2018-0061.

Shyr, W.-J., Pan, Y.-L., Huang, C.-C., \& Chang, S.-H. (2018). Development of competences for teppanyaki chefs in food and beverage education. British Food Journal, 12O(8), 1696-1707. https://doi.org/10.1108/BFJ02-2018-0122.

Sohn, E.-M., \& Lee, K.-W. (2018). The effect of chefs' nonverbal communication in open kitchens on service quality. Journal of Foodservice Business Research, 21(5), 483-492. https://doi.org/10.1080/15378020. 2018.1459125.

Stierand, M. B., \& Dörfler, V. (2012). Reflecting on a phenomenological study of creativity and innovation in haute cuisine. International Journal of Contemporary Hospitality Management, 24(6), 946-957. https://doi.org/10.1108/09596111211247254.

Stluka, S., Wells, K., \& McCormack, L. (2018). Power Chef Challenge: A Middle School Youth Cooking Curriculum. Journal of the Academy of Nutrition and Dietetics, 118(9, Supplement), A65. https://doi.org/https://doi.org/10.1016/j.jand.2018.06.025.

Suhairom, N., Musta'amal, A. H., Mohd Amin, N. F., Kamin, Y., \& Abdul Wahid, N. H. (2019). Quality culinary workforce competencies for sustainable career development among culinary professionals. International Journal of Hospitality Management, 81, 205-220. https://doi.org/https:// doi.org/10.1016/j.ijhm.2019.04.010.

Surlemont, B., Chantrain, D., Nlemvo, F., \& Johnson, C. (2005). Revenue models in haute cuisine: an exploratory analysis. International Journal of Contemporary Hospitality Management, 17(4), 286301. https://doi.org/10.1108/09596110510597561.

Swift, D., Malek, K., \& Swift, A. (2019). The Differences Between ACF Professional Chefs and Chef Educators: Concern for Task Versus Concern for People. Journal of Hospitality \& Tourism Education, 31(2), 8798. https://doi.org/10.1080/10963758.2018.1485496.

Taylor, E., \& Taylor, J. (2008). A new method of HACCP for hospitality: from concept to product. International Journal of Contemporary Hospitality Management, 2O(5), 524-541. https://doi.org/10.1108/ 09596110810881454. 
Tongchaiprasit, P., \& Ariyabuddhiphongs, V. (2016). Creativity and turnover intention among hotel chefs: The mediating effects of job satisfaction and job stress. International Journal of Hospitality Management, 55, 33-40. https://doi.org/https://doi.org/10.1016/j.ijhm.2016.02.009.

Tuparova, D., Kaseva, M., \& Tuparov, G. (2014). Development of Key Competences through ICT in Primary School. Procedia - Social and Behavioral Sciences, 116, 2952-2956. https://doi.org/https:// doi.org/10.1016/j.sbspro.2014.01.686.

Ulloa, A. M. (2019). The chef and the flavorist: reflections on the value of sensory expertise. Food, Culture \& Society, 22(2), 186-202. https://doi.org/10.1080/15528014.2019.1573042.

Verhaeghe, G., Vanhoof, J., Valcke, M., \& Van Petegem, P. (2011). Effects of supportof the use of school feedback. Pedagogische Studien, 88(2), 90-106. Retrieved from http://www.ijrvet.net/index.php/ IJRVET/article/view/259/76.

Wan, T.-H., Hsu, Y.-S., Wong, J.-Y., \& Liu, S.-H. (2017). Sustainable international tourist hotels: the role of the executive chef. International Journal of Contemporary Hospitality Management, 29(7), 1873-1891. https://doi.org/10.1108/IJCHM-08-2015-0406.

Wang, Y.-F., Horng, J.-S., Cheng, S.-Y. (Sophie), \& Killman, L. (2011). Factors influencing food and beverage employees' career success: A contextual perspective. International Journal of Hospitality Management, 3O(4), 997-1007. https://doi.org/https://doi.org/10.1016/j.ijhm.2011.03.005.

Warde, A. (2016). At the Chef's Table: Culinary Creativity in Elite Restaurants. Food, Culture \& Society, 19(3), 630-632. https://doi.org/10.1080/15528014.2016.1209292.

Wellton, L., Jonsson, I. M., \& Svingstedt, A. (2017). "Just trained to be a chef, not a leader": A study of head chef practices. International Journal of Hospitality \& Tourism Administration, 1-23. https://doi.org/ 10.1080/15256480.2017.1397584.

Wolfswinkel, J., Furtmueller-Ettinger, E., \& Wilderom, C. P. M. (2013). Using grounded theory as a method for rigorously reviewing literature. European Journal of Information Systems, 22, 45-55. https://doi.org/ https://doi.org/10.1057/ejis.2011.51.

Yang, B., \& Mattila, A. S. (2019). "Chef recommended" or "most popular"? Cultural differences in customer preference for recommendation labels. International Journal of Hospitality Management, 102390. https://doi.org/https://doi.org/10.1016/j.ijhm.2019.102390.

Yao-Fen, W. (2013). Constructing career competency model of hospitality industry employees for career success. International Journal of Contemporary Hospitality Management, 25(7), 994-1016. https://doi.org/10.1108/IJCHM-07-2012-0106.

Zhang, Y., \& Yu, X. (2018). Urban tourism and the politic of creative class: a study of the chefs in Macao. International Journal of Tourism Sciences, 18(2), 139-151. https://doi.org/10.1080/15980634. 2018.1471880.

Zopiatis, A. (2010). Is it art or science? Chef's competencies for success. International Journal of Hospitality Management, 29(3), 459-467. https://doi.org/10.1016/j.ijhm.2009.12.003.

Zopiatis, A., \& Constanti, P. (2007). "And never the twain shall meet" Investigating the hospitality industryeducation relationship in Cyprus. Education + Training, 49(5), 391-407. https://doi.org/10.1108/ 00400910710762959.

*** ASEAN. (2013). ASEAN Mutual Recognition Arrangment (MRA) on Tourism Professionals Handbook. Jakarta: ASEAN.

*** Culinary Institute of America. (2012). The professional chef. New York: John Wiley and Sons.*** Expedia. (2016). Ældre er mere eventyrlystne. Retrieved from Press release website: http://www.mynewsdesk.com/dk/expedia-denmark/pressreleases/aeldre-er-mere-eventyrlystne-1442638.

*** Oxford Dictionary Online. (2019). Definition of chef in English. Retrieved May 15, 2019, from https://en.oxforddictionaries.com/definition/chef. *** Wikipedia. (2019). Cook (profession). Retrieved May 15, 2019, from https://en.wikipedia.org/wiki/Cook_(profession).

Submitted:

31.07.2019
Revised:

11.11.2019
Accepted and published online 13.11.2019 